DOI https://doi.org/10.30525/978-9934-26-004-9-128

\title{
«НОВАЯ ПРОСТОТА» В СОВРЕМЕННОМ МУЗЫКАЛЬНОМ ИСКУССТВЕ (ПОНЯТИЙНО-ТЕРМИНОЛОГИЧЕСКИЙ АСПЕКТ)
}

\author{
Овсянникова-Трель А. А. \\ кандидат искусствоведения, \\ доцент кафедры истории музыки и музыкальной этнографии \\ Одесской национальной музыкальной академии \\ имени А. В. Неждановой \\ г. Одесса, Украина
}

В разнообразии стилевых проявлений современного музыкального искусства установка на упрощение музыкального языка в рамках индивидуально-композиторского стиля является устойчивой стилевой тенденцией, которая связана с новым вектором развития художественноэстетических нормативов «искусства интонируемого смысла» и творческих представлений о задачах и функциях музыки как формы культуры и вида художественной практики. Эта тенденция в музыковедческом дискурсе уже привычно связывается с понятием «новой простоты», закрепившемся за тем направлением композиторской практики, которое от последних десятилетий XX столетия ориентировано на нивелирование стилевого индивидуализма как основного посыла творческой деятельности и изначальным импульсом создания новых языков, жанров и стилей музыкального искусства в процессе его исторической эволюции. В этом смысле «новая простота» как явление профессиональной европейской музыки весьма репрезентативно в отношении современных концепций художественного творчества - как композиторских («конец времени композиторов» и «зона opus posth» В. Мартынова), так и философско-культурологических в целом (эпоха пост-культуры и мета-модерна), - которые провозглашают принципиальную невозможность создания чего-либо нового в музыке и, соответственно, неизбежность манипулирования «прошлым» музыкального искусства.

Как показывает практика, идеи «новой простоты» распространились на очень широком географическом пространстве: сегодня с уверенностью можно утверждать, что данное явление можно рассматривать в общеевропейском масштабе, его представляют 
композиторы самых различных стран, которые известны не только в сфере музыкального академизма, но и в киноиндустрии, в различных направлениях неакадемической музыки и т.п. Тем не менее, музыковедческое осмысление феномена «новой простоты» как целостного системного явления современного музыкального искусства ещё не состоялось, и эта ситуация вполне закономерна, поскольку практический музыкальный опыт в данном случае создаёт основные предпосылки его теоретического познания.

Понятие «новая простота» фиксирует кардинальное изменение того вектора композиторских представлений о сущности и функциях музыкального искусства, который сформировался в лоне авангардистской парадигматики музыкального творчества и определил принципиально инновационный подход композиторов к системе музыкального языка и его отдельных элементов (апогеем которого, безусловно, является тотальный сериализм К. Штокхаузена). Суть «нового» в «новой простоте» заключается в отказе от необходимости постоянного изменения нормативов музыкального языка и его тотальной индивидуализации, а также в возвращении к более доступному («простому») стилю музыкального выражения. Возвращение «новой простоты» К трезвучию и консонансу в качестве основных конструктивных элементов музыкального языка, представляет принципиально иной подход современных композиторов к технике музыкальной композиции в условиях «запрета на созвучие», провозглашённого западноевропейским музыкальным авангардом ХХ столетия. Причём «новым» в данном случае является само понимание основной функции трезвучия и консонанса: оно связано не столько с функциональной стороной тональных соотношений, сколько с фоническим обликом музыки, т. е. с тем фактором музыкального выражения, который обеспечивает его гармоничность и ясность в смысле слухового восприятия и возможность эмоционального отклика.

Как показывает история, в переходные эпохи музыкального искусства, на гребне поисков и экспериментов, связанных с усложнением музыкального языка, всегда появляется стилевая антитеза, суть котоой заключается в стремлении к более простому способу музыкального выражения. Многочисленные проявления «простого» стиля в музыкальном искусстве XX века всегда расценивались современниками как результат нового композиторского взгляда на музыку, порождающего её новое стилевое качество: так, достаточно экстремистские в своей экстравагантности произведения Э. Сати составляли стилевую антитезу музыкальному импрессионизму, а 
неопримитивизм К. Орфа можно рассматривать как противопоставление субъективному, эмоционально заострённому мироощущению музыкального экспрессионизма. Каждый раз «простота» представляла собой обратную сторону, иной лик «новизны», не повторяя того, что «уже было» буквально и не допуская банальности, проявляя при этом тонкие нити преемственности традиций. В конце XX века обозначенные тенденции оформились в радикализм иного рода, составляющий концептуальные основания того вектора композиторского творчества, который сегодня определяется понятием «новой простоты»: будь это «нулевой стиль» В. Мартынова, декларирующий в концепции opus-posth музыки принципиальную неузнаваемость Автора и отказ от его индивидуального «языкового кода», или «новая консонантнисть» Г. Пелециса, воплощающая индивидуально-композиторские идеалы эвфонии, или же «слабый стиль» В. Сильвестрова, апеллирующий к уже знакомому материалу.

С формальной точки зрения основной принцип «простоты» музыкального выражения в «новой простоте» связан с элементарным упрощением звукового ландшафта и переносом сложности структурных соотношений во внутренний слой музыкального языка и его исполнительское озвучивание. Однако, если подходить к «новой простоте» как системному стилевому явлению, обнаруживается, что композиторские представления о «простой» музыке охватывают различные уровни музыкального выражения и демонстрируют индивидуальные критерии как простоты музыкального языка, что обусловливает специфику музыкальной лексики каждого отдельного автора, так и «простоты» образно-смыслового содержания музыки, следствием чего становится множественность индивидуальных концепций «простого» стиля.

Основным фактором новизны в стилевой концепции «новой простоты» является композиторская установка на возвращение утраченных смыслов и возможностей музыкального языка путем изменения интеллектуального и структурного принципа музыкальной композиции на эмоциональный, что отражает идею реабилитации лирико-исповедального дискурса композиторского творчества как актуальную для музыкального искусства на рубеже XX-XXI веков. Возникновение этого стремления вполне закономерно в общем контексте развития европейского музыкального искусства прошлого столетия, претерпевшего радикальный разрыв с традициями не только художественно-эстетического порядка, но и философскомировоззренческими, что породило потребность эмоционального 
переживания музыки и смысловой определенности её интонационного словаря. Так, среди основного утраченного смысла музыки оказывается красота и ясность музыкального выражения, которые становятся основными интенциями композиторского творчества, репрезентующего стилевую тенденцию «новой простоты», и обусловливающие централизацию консонанса в системе музыкального языка того или иного композитора и принцип простой фактуры, обеспечивающий «прозрачность» музыкального смысла посредством «открытости» первоэлементов музыкального языка (мелодии, ритма и гармонии).

Еще один уровень «нового» в «новой простоте» проявляется не столько в музыкально-технологической плоскости, сколько в концептуальной - в самом композиторском понимании новизны как необходимого фактора музыкального творчества. Это понимание заключается в отказе от авторского «маркера» музыкального языка, а также в принципе манипулирования «словарным запасом» прошлых эпох европейского музыкального искусства, что априори порождает интертекстуальные свойства музыкального текста и его диалогический смысл.

DOI https://doi.org/10.30525/978-9934-26-004-9-129

\title{
УКРАЇНСЬКЕ ЦЕРКОВНО-МОНОДИЧНЕ МИСТЕЦТВО У ВІТЧИЗНЯНИХ РУКОПИСНИХ ДЖЕРЕЛАХ КІНЦЯ XVI - XVIII CT.
}

\author{
Путятицька О. В. \\ кандидат мистеитвознавства, доиент, \\ в.о. професора кафедри історії української музики \\ та музичної фольклористики \\ Національної музичної академії України імені П. І. Чайковського \\ м. Київ, Україна \\ Українське церковно-монодичне мистецтво кінця XVI - поч. XVII ст. \\ відзначається неймовірним кульмінаційним злетом. Водночас, зі стійким \\ побутуванням одноголосся, у період з кінця XVII - XVIII ст. домінує вже \\ українська духовна багатоголосна музика, що за своїм високим художнім \\ рівнем не поступалась тогочасній західноєвропейській бароковій музиці.
}

